\title{
Assessment of Undiscovered Oil Resources in the Devonian-Mississippian Bakken Formation, Williston Basin Province, Montana and North Dakota, 2008
}

Using a geology-based assessment methodology, the U.S. Geological Survey estimated mean undiscovered volumes of 3.65 billion barrels of oil, 1.85 trillion cubic feet of associated/dissolved natural gas, and 148 million barrels of natural gas liquids in the Bakken Formation of the Williston Basin Province, Montana and North Dakota.

\section{Introduction}

The U.S. Geological Survey (USGS) completed an assessment of the undiscovered oil and associated gas resources of the Upper Devonian-Lower Mississippian Bakken Formation in the U.S. portion of the Williston Basin of Montana and North Dakota and within the Williston Basin Province (fig. 1). The assessment is based on geologic elements of a total petroleum system (TPS) that include (1) source-rock distribution, thickness, organic richness, maturation, petroleum generation, and migration; (2) reservoir-rock type (conventional or continuous), distribution, and quality; and (3) character of traps and time of formation with respect to petroleum generation and migration. Detailed framework studies in stratigraphy and structural geology and the modeling of petroleum geochemistry, combined with historical exploration and production analyses, were used to aid in the estimation of the undiscovered, technically recoverable oil and associated gas resources of the Bakken Formation in the United States. Using this framework, the USGS defined a Bakken-Lodgepole TPS (fig. 1) and seven assessment units (AU) within the TPS. For the Bakken Formation, the undiscovered oil and associated gas resources within six of these assessment units were quantitatively estimated (fig. 2, table 1). A conventional AU within the Lodgepole Formation was not assessed.

\section{Bakken Formation and Bakken-Lodgepole Total Petroleum System}

The Upper Devonian-Lower Mississippian Bakken Formation is a thin but widespread unit within the central and deeper portions of the Williston Basin in Montana, North Dakota, and the Canadian Provinces of Saskatchewan and Manitoba. The formation consists of three members: (1) lower shale member, (2) middle sandstone member, and (3) upper shale member. Each succeeding member is of greater geographic extent than the underlying member. Both the upper and lower shale members are organic-rich marine shale of fairly consistent lithology; they are the petroleum source rocks and part of the continuous reservoir for hydrocarbons produced from the Bakken Formation. The middle sandstone member varies in thickness, lithology, and petrophysical properties, and local development of matrix porosity enhances oil production in both continuous and conventional Bakken reservoirs. Within

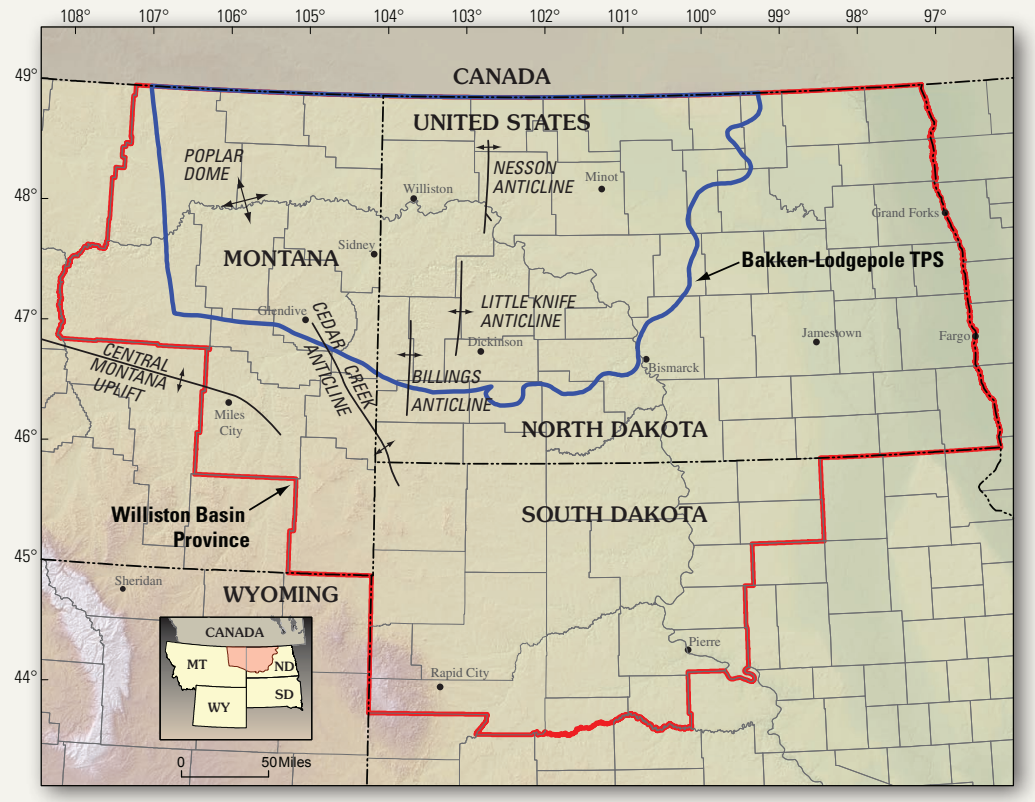

Figure 1. Map showing Williston Basin Province boundary (in red), Bakken-Lodgepole Total Petroleum System (TPS) (in blue), and major structural features in Montana, North Dakota, and South Dakota.

the Bakken-Lodgepole TPS, the upper and lower shale members of the Bakken Formation are also the source for oil produced from reservoirs of the Mississippian Lodgepole Formation.

\section{Geologic Model and Assessment Units}

The geologic model used to define AUs and to assess the Bakken Formation resources generally involves thermal maturity of the Bakken shale source rocks, petrophysical character of the middle sandstone member, and structural complexity of the basin. Most important to the Bakken-Lodgepole TPS and the continuous AUs within it are (1) the geographic extent of the Bakken Formation oil generation window (fig. 2), (2) the occurrence and distribution of vertical and horizontal fractures, and (3) the matrix porosity within the middle sandstone member. The area of the oil generation window for the Bakken continuous reservoir was determined by contouring both hydrogen index and well-log resistivity values of the upper shale member, which is youngest and of greatest areal extent.

The area of the oil generation window for the Bakken Formation was divided into five continuous AUs: (1) Elm Coulee-Billings Nose AU, (2) Central Basin-Poplar Dome AU, (3) Nesson-Little Knife Structural AU, (4) Eastern Expulsion Threshold AU, and (5) Northwest Expulsion Threshold AU. A sixth hypothetical conventional AU, a Middle Sandstone Member AU, was defined external to the area of oil generation. 
Table 1. Bakken Formation, Williston Basin Province assessment results.

[MMBO, million barrels of oil. BCFG, billion cubic feet of gas. MMBNGL, million barrels of natural gas liquids. Results shown are fully risked estimates.

F95 represents a 95 percent chance of at least the amount tabulated; other fractiles are defined similarly. TPS, total petroleum system; AU, assessment unit]

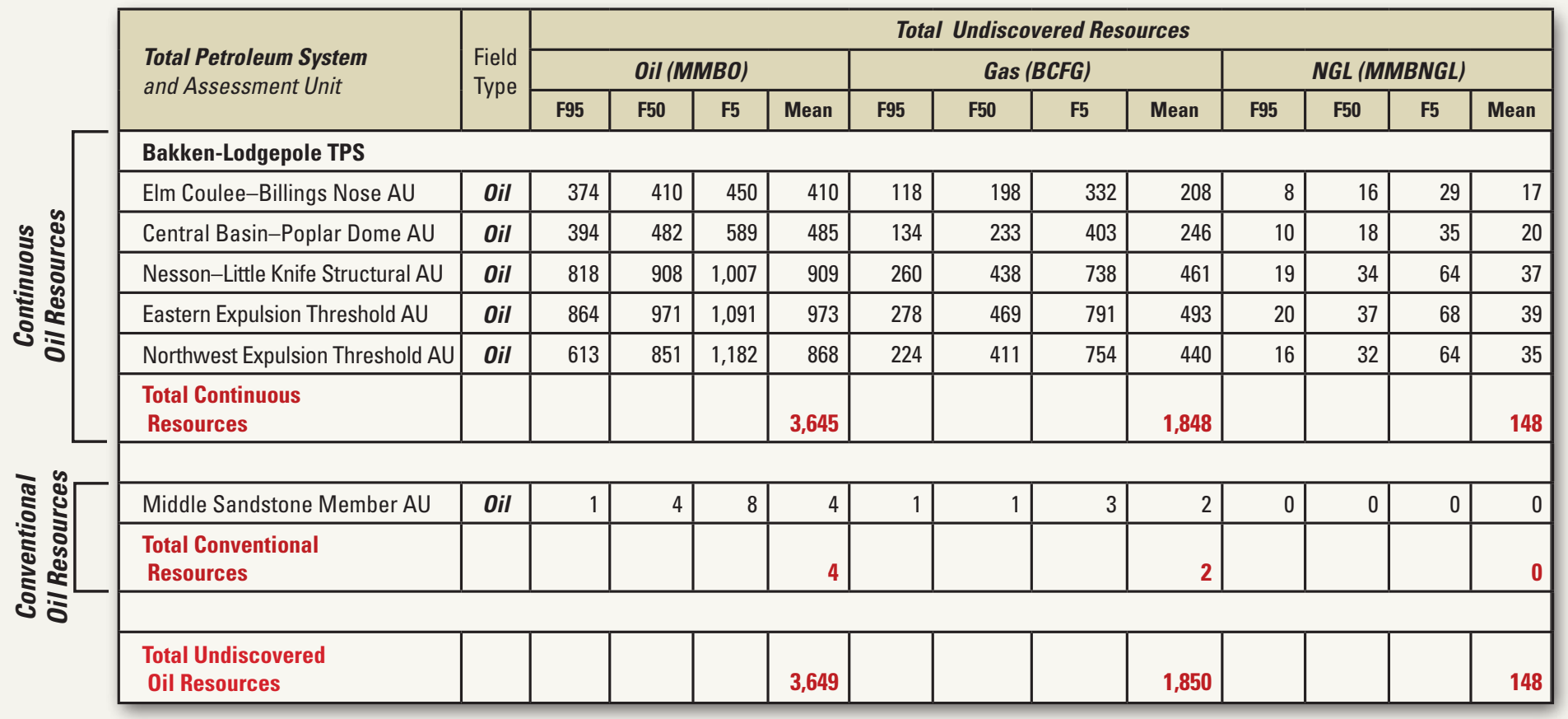

\section{Resource Summary}

The USGS assessed undiscovered oil and associated gas resources in five continuous (unconventional) AUs and one conventional AU for the Bakken Formation (fig. 2; table 1). For continuous oil resources, the USGS estimated a total mean resource of 3.65 billion barrels of oil, which combines means of 410 million barrels in the Elm Coulee-Billings Nose AU, 485 million barrels in the Central Basin-Poplar Dome AU, 909 million barrels in the Nesson-Little Knife Structural AU, 973 million barrels in the Eastern Expulsion Threshold AU, and 868 million barrels in the Northwest Expulsion Threshold AU. A mean resource of 4 million barrels was estimated for the conventional Middle Sandstone Member AU.

The assessment of the Bakken Formation indicates that most of the undiscovered oil resides within a continuous composite reservoir that is distributed across the entire area of the oil generation window (fig. 2) and includes all members of the Bakken Formation. At the time of this assessment, only a limited number of wells have produced from the Bakken continuous reservoir in the Central Basin-Poplar Dome AU, the Eastern Expulsion Threshold AU, and the Northwest Expulsion Threshold AU. Therefore, there is significant geologic uncertainty in these estimates, which is reflected in the range of estimates for oil (table 1).

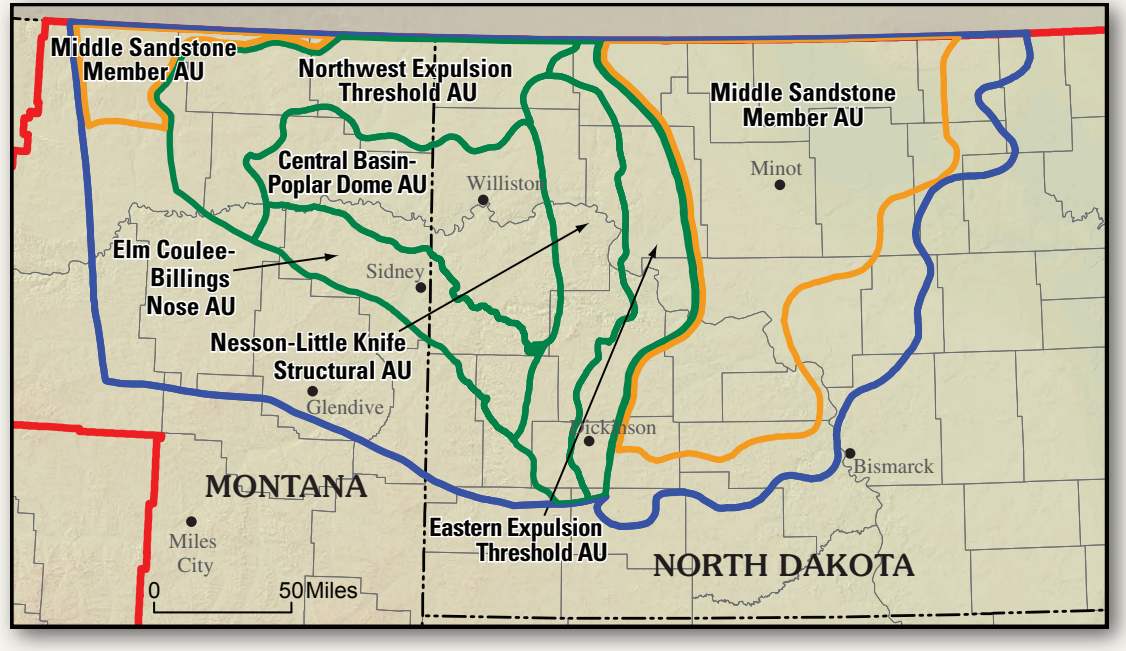

Figure 2. Map showing boundary of Bakken-Lodgepole Total Petroleum System (TPS) (in blue), five continuous assessment units (AU) (in green), and one conventional $A U$ (in orange) defined for the assessment of undiscovered oil resources in the Upper Devonian-Lower Mississippian Bakken Formation in the U.S. portion of the TPS. The outermost green line defines the area of oil generation for the upper shale member of the formation.

\section{Bakken Formation, Williston Basin Province Assessment Team}

Richard M. Pollastro (Bakken Formation Task Leader; pollastro@usgs.gov), Troy A. Cook, Laura N. R. Roberts, Christopher J. Schenk, Michael D. Lewan, Lawrence O. Anna, Stephanie B. Gaswirth, Paul G. Lillis, Timothy R. Klett, and Ronald R. Charpentier.

\section{For Further Information}

Supporting geologic studies of the total petroleum system and assessment units and the methodology used in the Bakken Formation, Williston Basin Province assessment are in progress. Assessment results are available at the USGS Central Energy Team website, http://energy.cr.usgs.gov/oilgas/noga. 